\title{
Characteristics of particulate matter collected at an urban background site and a roadside site in Birmingham, United Kingdom
}

\author{
Adewale M. TAIWO
}

\begin{abstract}
Division of Environmental Health Risk Management, School of Geography, Earth \& Environmental Sciences, University of Birmingham, Edgbaston, Birmingham, B15 2TT, United Kingdom; currently at the Department of Environmental Management and Toxicology, Federal University of Agriculture, PMB 2240, Abeokuta, Ogun State, Nigeria. Email: taiwoademat@gmail.com
\end{abstract}

Received: July 13, 2015; accepted: July 12, 2017

\begin{abstract}
RESUMEN
El objetivo del presente estudio fue investigar las características constitutivas del material particulado (MP) recolectado tanto en un contexto urbano (sitio de observación de Elms Road, SOER) como en un sitio ubicado junto al camino (sitio de observación de Bristol Road, SOBR). Las muestras de MP fueron recolectadas en los sitios receptores del 28 de marzo al 11 de abril de 2012. Los parámetros estudiados incluyeron iones solubles en agua $\left(\mathrm{Cl}^{-}, \mathrm{NO}_{3}^{-}, \mathrm{SO}_{4}^{2-}, \mathrm{Na}^{+}, \mathrm{NH}_{4}^{+}, \mathrm{K}^{+}, \mathrm{Mg}^{2+}, \mathrm{Ca}^{2+}\right.$ ) y trazas de metales $(\mathrm{V}, \mathrm{Al}, \mathrm{Cr}, \mathrm{Mn}, \mathrm{Fe}, \mathrm{Zn}, \mathrm{Cu}, \mathrm{Sb}, \mathrm{Ba}$, $\mathrm{Pb}$ ). Los resultados mostraron mayores concentraciones de $\mathrm{NO}_{3}^{-}, \mathrm{NH}_{4}^{+}, \mathrm{Al}$ y Fe en SOBR en comparación con SOER en relación con $\mathrm{MP}_{2.5}, \mathrm{y}$ de $\mathrm{Cl}^{-}, \mathrm{NO}_{3}^{-}, \mathrm{Na}^{+}, \mathrm{K}^{+}$y Fe con relación a $\mathrm{PM}_{2.5-10}$, lo cual es indicativo de incrementos a lo largo del camino. Los componentes iónicos y metálicos de $\mathrm{MP}_{2.5}$ en SOER constituyeron 44 y $7 \%$ de la masa total de MP medida, respectivamente. Las proporciones de estas especies fueron 46 y $8 \%$ en SOBR. En cuanto al $\mathrm{MP}_{2.5-10}$, los componentes solubles en agua y de trazas de metal representaron 42 y $12 \%$ en SOER, y 56 y $11 \%$ en SOBR.
\end{abstract}

\begin{abstract}
This study was conducted to investigate the compositional characteristics of particulate matter (PM) collected both at an urban background site (Elms Road observational site, EROS) and a roadside site (Bristol Road observational site, BROS). PM samples were collected at the receptor sites between March 28 and April 11, 2012. Observed parameters included water-soluble ions $\left(\mathrm{Cl}^{-}, \mathrm{NO}_{3}^{-}, \mathrm{SO}_{4}^{2-}, \mathrm{Na}^{+}, \mathrm{NH}_{4}^{+}, \mathrm{K}^{+}, \mathrm{Mg}^{2+}, \mathrm{Ca}^{2+}\right)$ and trace metals (V, Al, Cr, $\mathrm{Mn}, \mathrm{Fe}, \mathrm{Zn}, \mathrm{Cu}, \mathrm{Sb}, \mathrm{Ba}, \mathrm{Pb}$ ). Results showed higher concentrations of $\mathrm{NO}_{3}^{-}, \mathrm{NH}_{4}^{+}, \mathrm{Al}$ and $\mathrm{Fe}$ at BROS than EROS regarding $\mathrm{PM}_{2.5}$; and $\mathrm{Cl}^{-}, \mathrm{NO}_{3}^{-}, \mathrm{Na}^{+}, \mathrm{K}^{+}$and $\mathrm{Fe}$ regarding $\mathrm{PM}_{2.5-10}$, indicating roadside increments. The ionic and metal components of $\mathrm{PM}_{2.5}$ at EROS constituted 44 and $7 \%$ of the total measured PM mass, respectively. The proportions of these species were 46 and $8 \%$ at BROS. For PM $\mathrm{PM}_{2.5-10}$, water-soluble ions and trace metal components represented 42 and $12 \%$ at EROS, and 56 and $11 \%$ at BROS.
\end{abstract}

Keywords: Particulate matter, roadside increment, water-soluble ions, trace metals.

\section{Introduction}

Particles are emitted from numerous anthropogenic and natural activities. The prominent sources of particulate matter $(\mathrm{PM})$ in cities and urban areas include: (a) traffic, (b) secondary, industrial, crustal, and marine combustion activities, and (c) power plants
(Levy et al., 2003; Charron and Harrison, 2005; Liu and Harrison, 2011; Taiwo et al., 2014). The presence of high concentrations of particulate matter could pose serious environmental and health concerns. Although measures have been put in place by developed nations to abate air pollution, epidemiological 
studies still show that current air pollution episodes are capable of causing harm to the public. The Natural Resources Defense Council reported that particulate air pollution causes 64000 deaths annually in the United States (Mysliwiec and Kleeman, 2002). In Europe, Watkiss et al. (2005) have reported around 350000 annual premature deaths, while at the global scale more than one million deaths per year are recorded due to exposure to ambient particulate matter (WHO, 2009; Anenberg et al., 2010).

The contribution of traffic to $\mathrm{PM}_{2.5}, \mathrm{PM}_{2.5-10}$ and $\mathrm{PM}_{10}$ was researched by Liu and Harrison (2011) in the UK. The results showed a significant increment at roadside sites relative to urban background sites. This study also indicated industrial and marine aerosol as major contributors to coarse PM in the UK. A related study by Harrison et al. (2012) also showed an elevated mean concentration of $\mathrm{PM}_{2.5}$ at roadside sites as compared to background sites. The aim of this study is to compare PM compositional data collected at urban background and traffic sites.

\section{Materials and methods}

\subsection{Description of the study areas}

The Elms Road observatory site (EROS; $1.93^{\circ} \mathrm{W}$, $52.46^{\circ} \mathrm{N}$ ) is a typical urban background site, located on an open field within the University of Birmingham campus. The nearest roads are lightly trafficked and the nearby railway line carries mainly electric trains. The Bristol Road observatory site (BROS; $1.93^{\circ} \mathrm{W}$, $52.45^{\circ} \mathrm{N}$ ) is a traffic-polluted site also located within the University of Birmingham campus. These two sites are about $3.5 \mathrm{~km}$ southwest of the center of Birmingham, whose population is over one million and is part of a conurbation of 2.5 million people (Yin et al., 2010). EROS and BROS sites are shown in Figure 1.

\subsection{Particulate matter sampling}

Particle sampling was carried out with Partisol samplers placed at the two monitoring sites within the University of Birmingham for two weeks between March 28 and April 11.

\subsection{Sample analysis}

Prior to sampling and after this process, all filters were weighed with a Sartorius microbalance (Model MC 5; 1 pg sensitivity), which was equipped with a

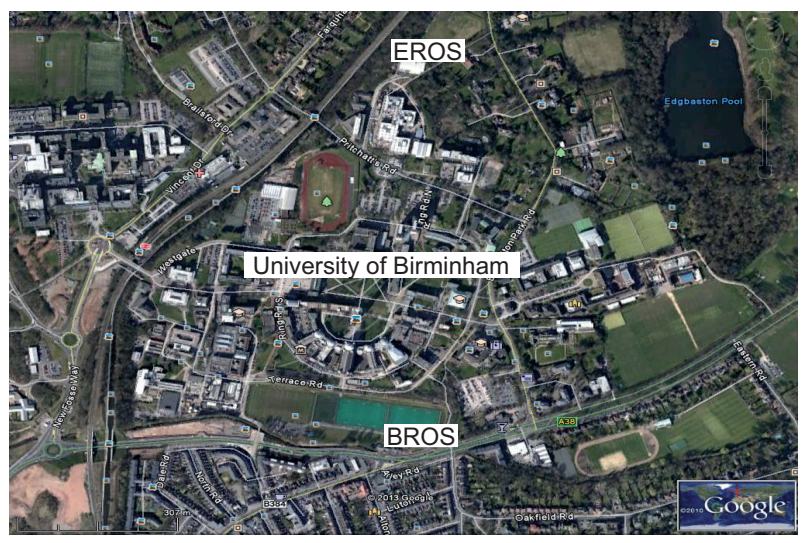

Fig. 1. Location of EROS and BROS monitoring sites.

Polonium-210 anti-static source and had been subjected to at least $24 \mathrm{~h}$ pre-conditioning $\left(25 \pm 5^{\circ} \mathrm{C}\right.$ and $30 \pm 10 \% \mathrm{RH})$ in our clean weighing room.

\subsection{Metals analysis}

All exposed Teflon filters were cut into two equal portions. One-half portion was digested for metal analysis by the reverse aqua regia procedures described in Harrison et al. (2003). Filters were digested in a solution of mixed concentrated acids $(2.23 \mathrm{M}$ $\mathrm{HCl}$ and $1.03 \mathrm{M} \mathrm{HNO}_{3}$, ultra-pure grade) prepared by mixing concentrated nitric acid $(65 \mathrm{ml})$ and concentrated hydrochloric acid $(185 \mathrm{ml})$ in a $1000 \mathrm{~cm}$ volumetric flask and making up to $1 \mathrm{~L}$ with distilled deionized water. The mixed acid extractant $(2 \mathrm{ml})$ was introduced into filters placed inside $4 \mathrm{ml}$ narrow neck bottles and heated at $100{ }^{\circ} \mathrm{C}$ for 30 minutes in a water bath and then placed in an ultrasonic bath at $50{ }^{\circ} \mathrm{C}$ for another $30 \mathrm{~min}$. This cycle was repeated and the ready digests transferred into $15 \mathrm{ml}$ narrow neck bottles and made up to $10 \mathrm{ml}$ with distilled deionized water. The ready extracts of filter samples were then analyzed using an inductively coupled plasma mass spectrometer (ICPMS, Agilent $7500 \mathrm{Ce}$ ) at the University of Birmingham. The version of this ICPMS is a quadrupole equipped with an octopole reaction system that removes interfering species. Metals of interest were $\mathrm{Al}, \mathrm{Mn}, \mathrm{Cr}, \mathrm{V}, \mathrm{Fe}, \mathrm{Zn}, \mathrm{Cu}, \mathrm{Ni}, \mathrm{Cd}, \mathrm{Sb}$, $\mathrm{Ba}$ and $\mathrm{Pb}$. The mixed standards (from the stock $1000 \mathrm{mg} \mathrm{L}^{-1}$ VWR standard solution) were prepared in series of $0,1,5,10,20,50$ and $100 \mu \mathrm{g} \mathrm{L}^{-1}$. Internal standards used for ICPMS analysis were Sc, Ge, Y, In and $\mathrm{Bi}$. 


\subsection{Water soluble ions analysis}

The second half of the exposed filter samples was analyzed for water-soluble ions (cations $\mathrm{Na}^{+}, \mathrm{K}^{+}$, $\mathrm{Mg}^{2+}, \mathrm{Ca}^{2+}, \mathrm{NH}_{4}^{+}$; anions $\mathrm{Cl}^{-1}, \mathrm{NO}_{3}^{-}, \mathrm{SO}_{4}^{2}, \mathrm{C}_{2} \mathrm{O}_{2}{ }^{2-}$, $\mathrm{PO}_{4}^{3-}$ ). The filter samples were leached with $7.5 \mathrm{ml}$ distilled deionized water in a Sonicator for $30 \mathrm{~min}$. The leachates were measured with Dionex ICS 2000 and DX 500 for anions and cations, respectively.

An Ion Chromatography System (ICS) was employed for the analysis of water-soluble anions. The samples were loaded into an auto sampler in $0.5 \mathrm{ml}$ vials. The sample was injected into the eluent stream of the instrument. For the anionic component (Dionex ICS 2000), the eluent used was potassium hydroxide $(\mathrm{KOH})$. The eluent and the sample were pumped through an analytical (separator) column (AS $11 \mathrm{HC}$, $2 \times 250 \mathrm{~mm}$ ) and a guard column (AG $11 \mathrm{HC}, 2 \times 50$ $\mathrm{mm}$ ) for separation or ion exchange and contaminants removal, respectively (Thermo Fischer Scientific Inc., 2012). For water-soluble cations, the IC employed was Dionex DX 500 equipped with CS 12A analytical column $(4 \times 250 \mathrm{~mm})$ and CG12A guard column $(4 \times 50 \mathrm{~mm})$ (Thermo Fischer Scientific Inc., 2012). The eluent solution used was $1 \mathrm{~N}$ methane sulphonic acid. Calibration curves (for anions and cations) were obtained with series of mixed standard solutions prepared in the range concentration between 0.5 and $10 \mathrm{mg} \mathrm{L}^{-1}$. Ten blank filters were run for all the elemental concentrations to cancel the matrix effect of background levels.

\section{Results}

\subsection{Partisol PM composition at EROS and BROS}

Figures 2 and 3 show the mean mass and chemical composition of $\mathrm{PM}_{2.5}$ and $\mathrm{PM}_{2.5-10}$ at EROS and BROS. The two sites show higher mass concentration of $\mathrm{PM}_{2.5}$ than $\mathrm{PM}_{2.5-10}$, signifying more influence of anthropogenic emissions. The two categories of PM were higher at BROS, probably due to traffic contribution. The water-soluble components of PM showed predominance of $\mathrm{NO}_{3}^{-}$at BROS and $\mathrm{SO}_{4}^{-}$at EROS. The order of abundance of species in $\mathrm{PM}_{2.5}$ at EROS is as follows: sulphate $\left(17 \%\right.$ of $\left.\mathrm{PM}_{2.5}\right)$, nitrate $(13 \%)$, ammonium (12\%) and $\mathrm{Al}(6 \%)$. The water-soluble and trace metal species constituted 44 and $7 \%$ of the measured $\mathrm{PM}_{2.5}$ mass concentration, respectively. In the $\mathrm{PM}_{2.5-10}$ fraction, the sequence of abundance of species is as follows: $\mathrm{NO}_{3}^{-}>\mathrm{Al}>\mathrm{SO}_{4}^{-}>\mathrm{Cl}^{-}>\mathrm{Ca}^{2+}$
$>\mathrm{Na}^{+} / \mathrm{Fe}>\mathrm{Mg}^{2+}$. These components represented 42 and $12 \%$, respectively, for $\mathrm{PM}_{2.5-10}$. The remaining components of PM could be attributable to carbonaceous species that were not measured during the study.

At BROS, $\mathrm{NO}_{3}^{-}$constituted 20 and $24 \%$ of the total $\mathrm{PM}_{2.5}$ and $\mathrm{PM}_{2.5-10}$ mass concentration, respectively. The sequence followed 15 and $10 \%$ for $\mathrm{SO}_{4}^{2-}, 15$ and $1 \%$ for $\mathrm{NH}_{4}^{+}, 1$ and $7 \%$ for $\mathrm{Cl}^{-}, 1$ and $4 \%$ for $\mathrm{Na}^{+}, 8$ and $5 \%$ for $\mathrm{Al}$, and 1 and $5 \%$ for $\mathrm{Fe} . \mathrm{Mg}$ and $\mathrm{Ca}^{2+}$ occupied 1 and $4 \%$ of the $\mathrm{PM}_{2.5-10}$ mass, respectively. The measured components of $\mathrm{PM}_{2.5}$ showed dominance of water-soluble ions (46\%), while trace metals only constituted $8 \%$. A total fraction of $56 \%$ of the measured coarse mass concentration was attributed to ionic species and $11 \%$ to trace metals.

The influence of ammonium, nitrate and aluminum were prominent in $\mathrm{PM}_{2.5}$ at BROS while elevated $\mathrm{SO}_{4}^{2-}, \mathrm{V}$ and $\mathrm{Sb}$ were observed at EROS. $\mathrm{Cr}, \mathrm{Mn}, \mathrm{Zn}$ and $\mathrm{Cu}$ exhibited similarities in their concentrations at the two sites. Higher values were clearly observed for coarse $\mathrm{Cl}^{-}, \mathrm{Na}^{+}, \mathrm{Mg}^{2+}, \mathrm{K}^{+}, \mathrm{Cr}$, $\mathrm{Mn}, \mathrm{Fe}, \mathrm{Cu}$ and $\mathrm{Ba}$ at BROS. Reasons might be linked to more pronounced traffic emissions from exhaust and non-exhaust vehicular processes, and additionally from the sea spray source for water-soluble species (Mazzei et al., 2008).

Figure 4 depicts the relationship between $\mathrm{PM}_{2.5}$ and $\mathrm{PM}_{2.5-10}$ mass concentrations measured at EROS and BROS sites. $\mathrm{PM}_{2.5}$ data at the two sites are well correlated with a slope near 1.0. The strong relationship between $\mathrm{PM}_{2.5}$ at the sites is a confirmation of a common emission source; however, the relationship between $\mathrm{PM}_{2.5-10}$ data at both sites was poorly defined. The contribution of coarse fraction to PM load was slightly higher at BROS than EROS. This might be directly linked to re-suspension of road dust at BROS. The $\mathrm{PM}_{2.5} / \mathrm{PM}_{10}$ ratio has been calculated for Partisol samples at both sites, being 0.61 at EROS and 0.60 at BROS, which indicates anthropogenic emissions at these sites.

PM elemental differences between background (EROS) and roadside (BROS) sites are plotted in Fig. 5. There were convincing increments in the mean values of $\mathrm{NO}_{3}^{-}, \mathrm{NH}_{4}^{+}, \mathrm{Al}$ and $\mathrm{Fe}$ at the roadside for $\mathrm{PM}_{2.5}$; and $\mathrm{Cl}^{-}, \mathrm{NO}_{3}^{-}, \mathrm{SO}_{4}^{-}, \mathrm{Na}^{+}, \mathrm{K}^{+}$and $\mathrm{Fe}$ for $\mathrm{PM}_{2.5-10}$. Incremental parameters of $\mathrm{Fe}, \mathrm{Cl}^{-}$, and $\mathrm{Al}$ have been reported as markers for traffic in many published studies (Kleeman et al., 2000; 

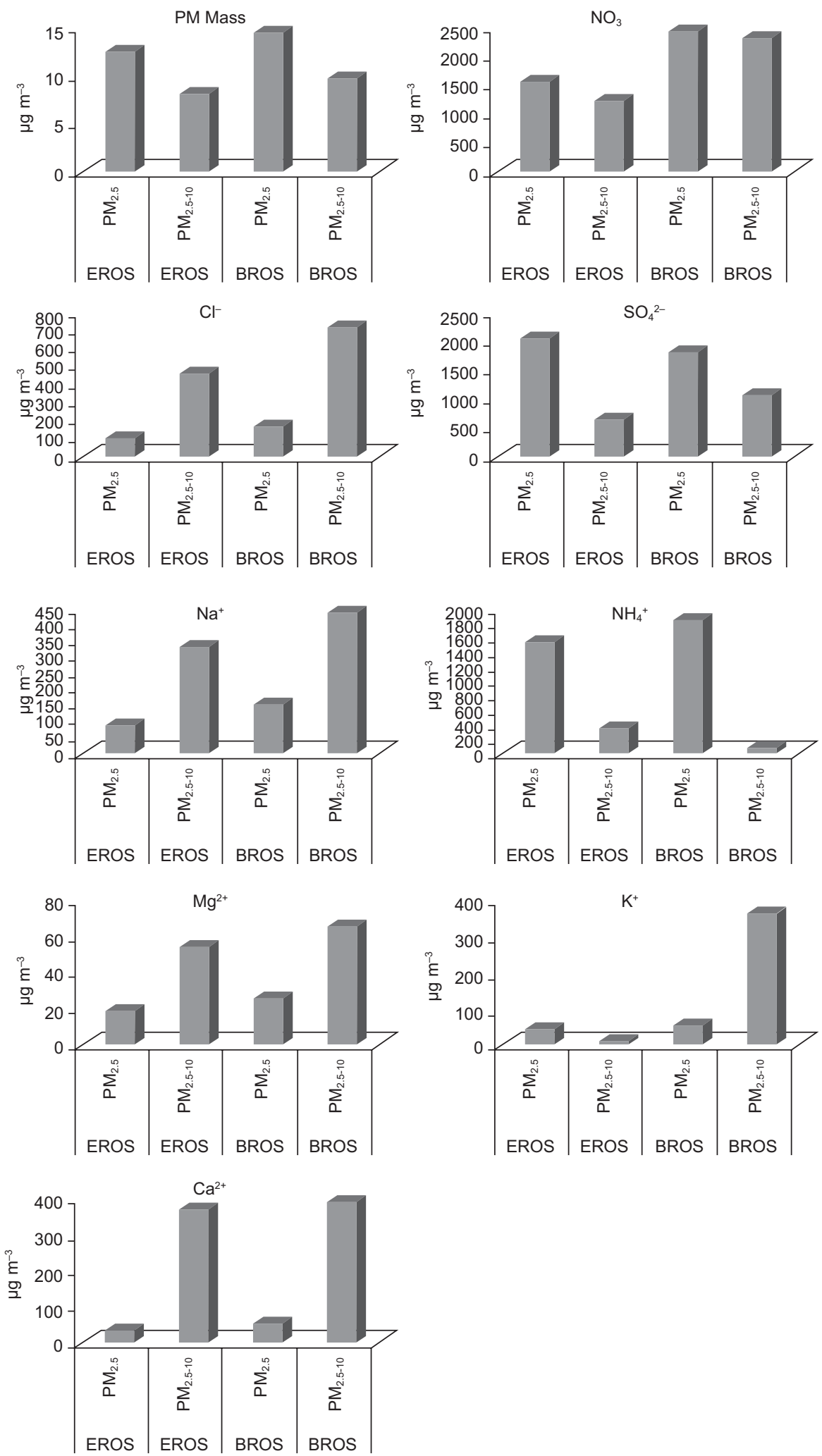

Fig. 2. Mass and water-soluble ions concentrations of PM analyzed in the study areas. 

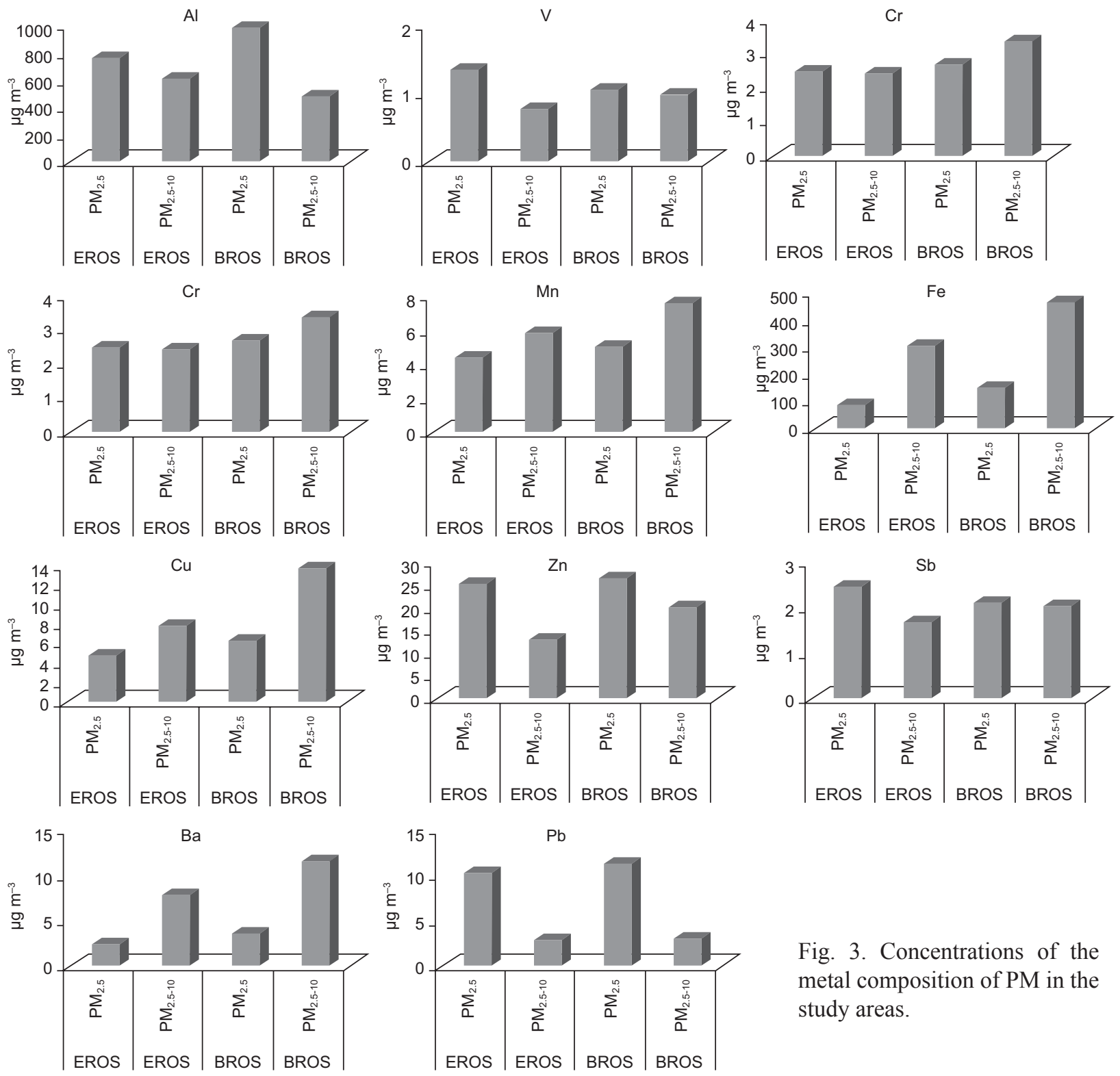

Fig. 3. Concentrations of the metal composition of PM in the study areas.
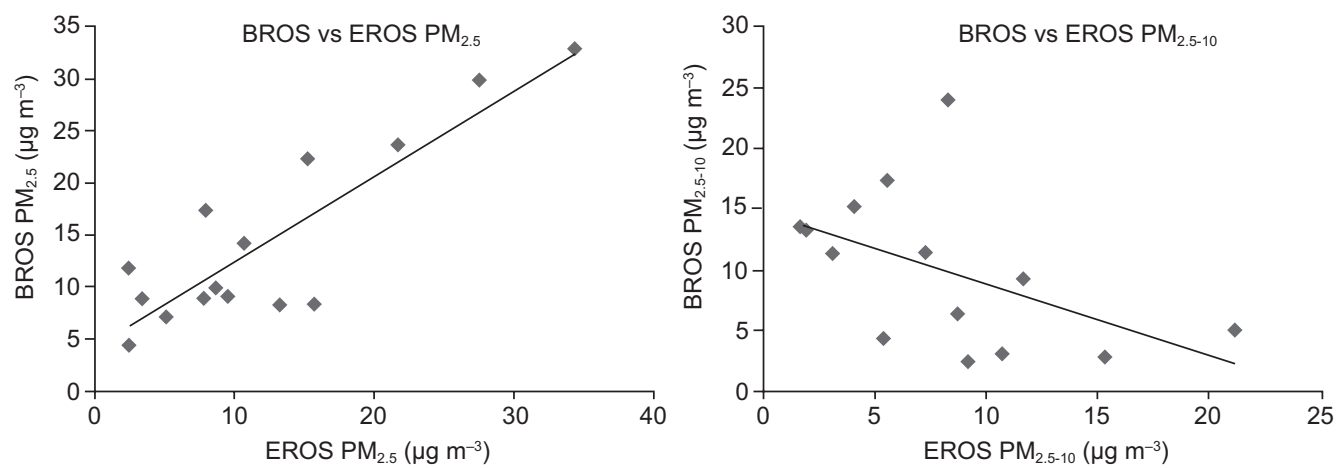

Fig. 4. Linear regression analysis of $\mathrm{PM}_{2.5}$ and $\mathrm{PM}_{2.5-10}$ at EROS and BROS. 

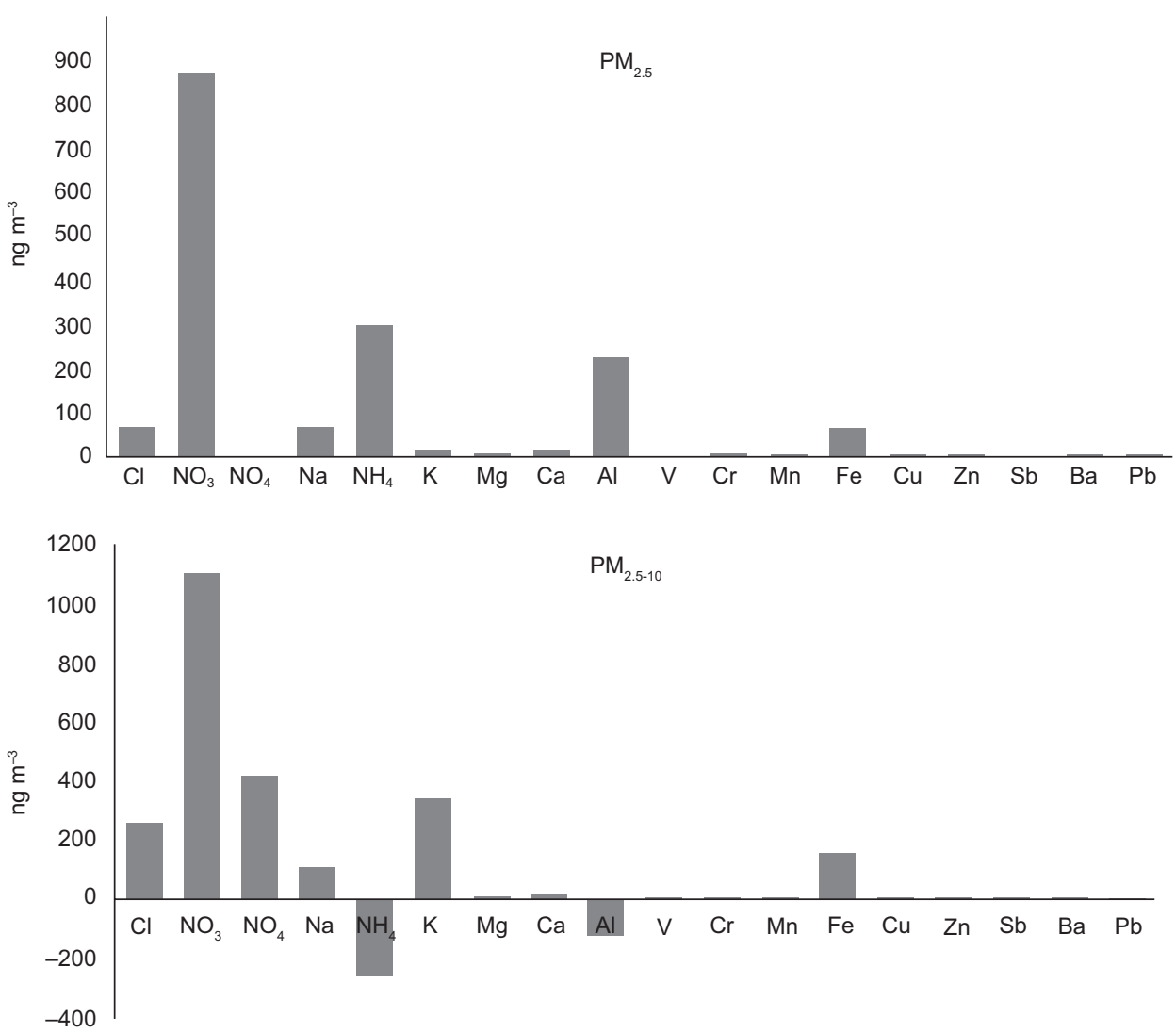

Fig. 5. PM elemental differences between background (EROS) and roadside (BROS) sites indicating roadside increments.

Chung et al., 2006; Lim et al., 2010; Xia and Gao, 2010). The higher values observed for roadside $\mathrm{Na}^{+}$ and $\mathrm{Cl}^{-}$might be traced to de-icing of salt or marine aerosol (Harrison et al., 2004). The higher concentrations of roadside $\mathrm{Fe}$ observed for $\mathrm{PM}_{2.5}$ and $\mathrm{PM}_{10}$ were in good agreement with previous studies by Harrison et al. (2003).

3.2 Pearson's correlation coefficients for $P M_{2.5}$ and PM 2.5-10 data at EROS and BROS

Pearson's correlation coefficients (r) of $\mathrm{PM}_{2.5}$ and $\mathrm{PM}_{2.5-10}$ at EROS and BROS are presented in Tables I-IV). EROS $\mathrm{PM}_{2.5}$ mass concentration exhibited good agreement with $\mathrm{NH}_{4}^{+}, \mathrm{K}^{+}, \mathrm{Fe}, \mathrm{Cr}, \mathrm{Mn}$, $\mathrm{Cu}, \mathrm{Zn}, \mathrm{Sb}, \mathrm{Ba}$ and $\mathrm{Pb}(\mathrm{r}=0.56-0.86 ; \mathrm{p}<0.05$ and 0.01). This shows that EROS fine PM might largely be influenced by woodsmoke/biomass burning, crustal sources and traffic emissions. A better correlation between $\mathrm{K}^{+}$and $\mathrm{NH}_{4}^{+}(\mathrm{r}=0.74 ; \mathrm{p}<0.01)$ could indicate likely emissions from woodsmoke and incineration (Lim et al., 2010). Most of the trace metals were highly associated with one another, especially
Fe with $\mathrm{Mn}$ and $\mathrm{Ba}$; and $\mathrm{Sb}$ with $\mathrm{Ba}, \mathrm{Zn}, \mathrm{Fe}$ and $\mathrm{Pb}$. This could signify crustal and traffic emissions. The marine influence was prominent in EROS $\mathrm{PM}_{2.5}$ with evidence of solid association between $\mathrm{Na}^{+}$and $\mathrm{Cl}^{-}$ $(\mathrm{r}=0.78 ; \mathrm{p}<0.01)$.

The $\mathrm{PM}_{2.5-10}$ mass concentration at EROS showed strong correlations with $\mathrm{NH}_{4}^{+}, \mathrm{K}^{+}, \mathrm{Ca}^{2+}, \mathrm{Fe}, \mathrm{Cr}, \mathrm{Mn}$, $\mathrm{Cu}, \mathrm{Zn}, \mathrm{Ba}$ and $\mathrm{Pb}(\mathrm{r}=0.68-0.86 ; \mathrm{p}<0.01)$. A strong relationship was established for $\mathrm{Na}^{-}$and $\mathrm{Cl}^{-}$ $(\mathrm{R}=0.95 ; \mathrm{p}<0.01)$. Mn and Fe were significantly correlated, indicating a similar emission source, probably crustal or industrial. Aluminum did not correlate well with Fe and Mn, suggesting their separate emission sources. Strong associations were established among the traffic signatures $\mathrm{Sb}, \mathrm{Fe}, \mathrm{Cu}$, $\mathrm{Zn}$ and $\mathrm{Ba}$ in coarse PM.

Pearson's correlations for $\mathrm{PM}_{2.5}$ mass with other constituents at BROS were similar to those observed at EROS. The association of $\mathrm{NH}_{4}^{+}$with $\mathrm{SO}_{4}$ and $\mathrm{NO}_{3}$, though weak, were better defined in $\mathrm{PM}_{2.5}$ at BROS than at EROS. Mg and Ca were also strongly 


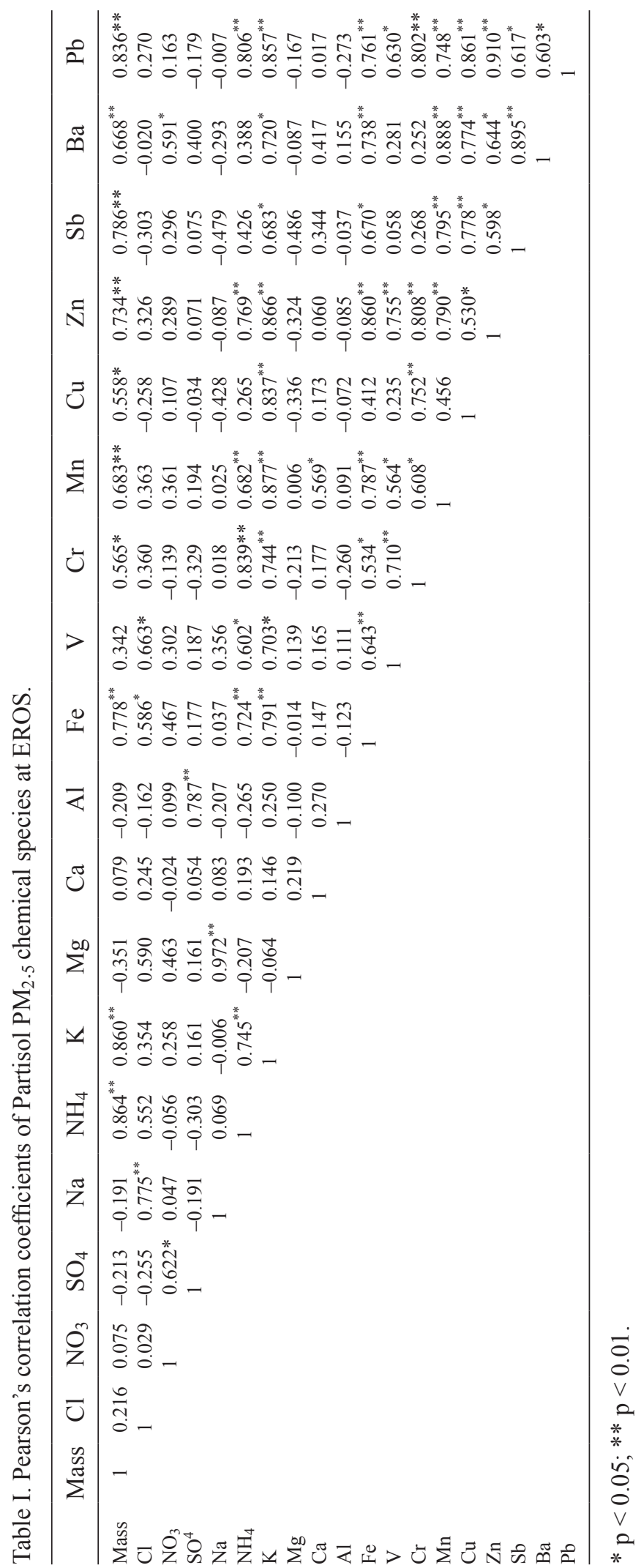




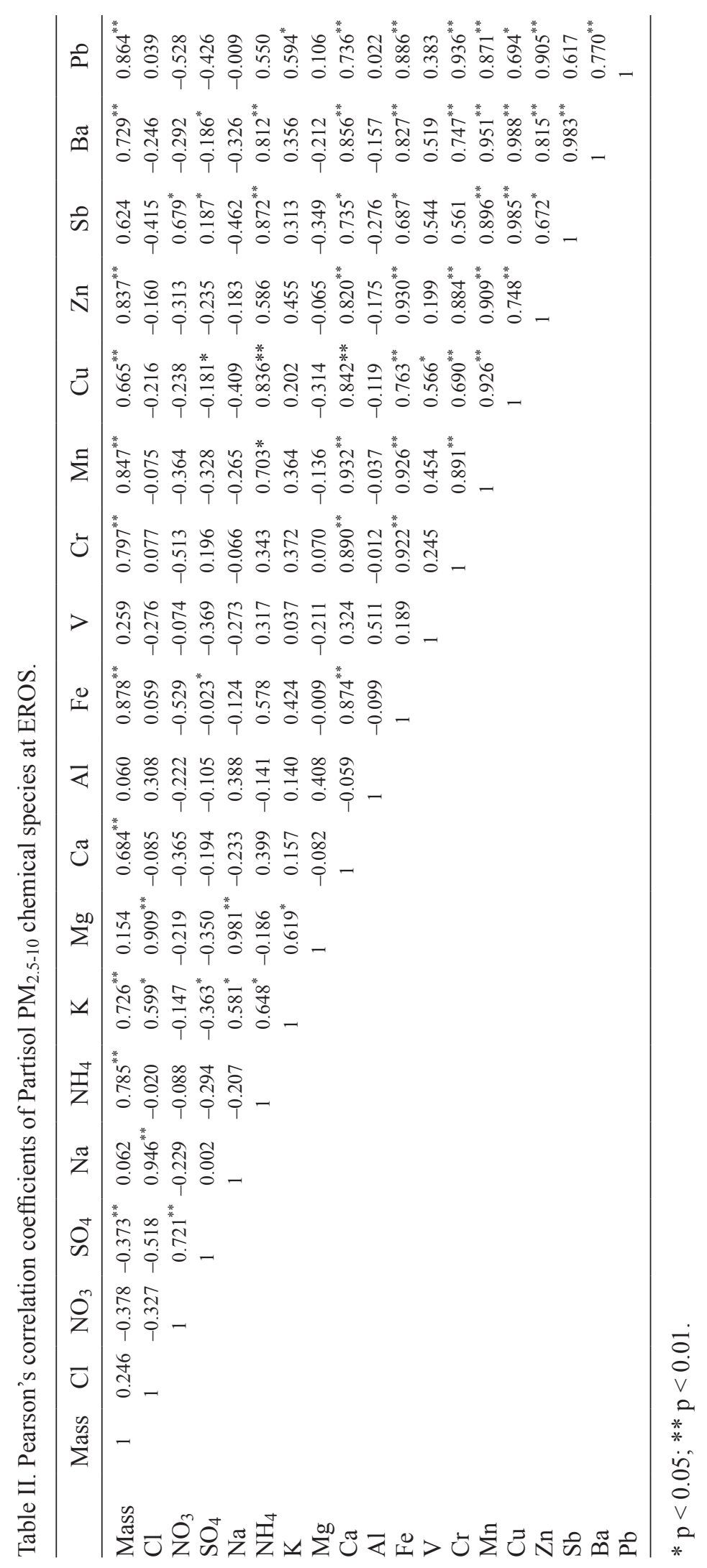




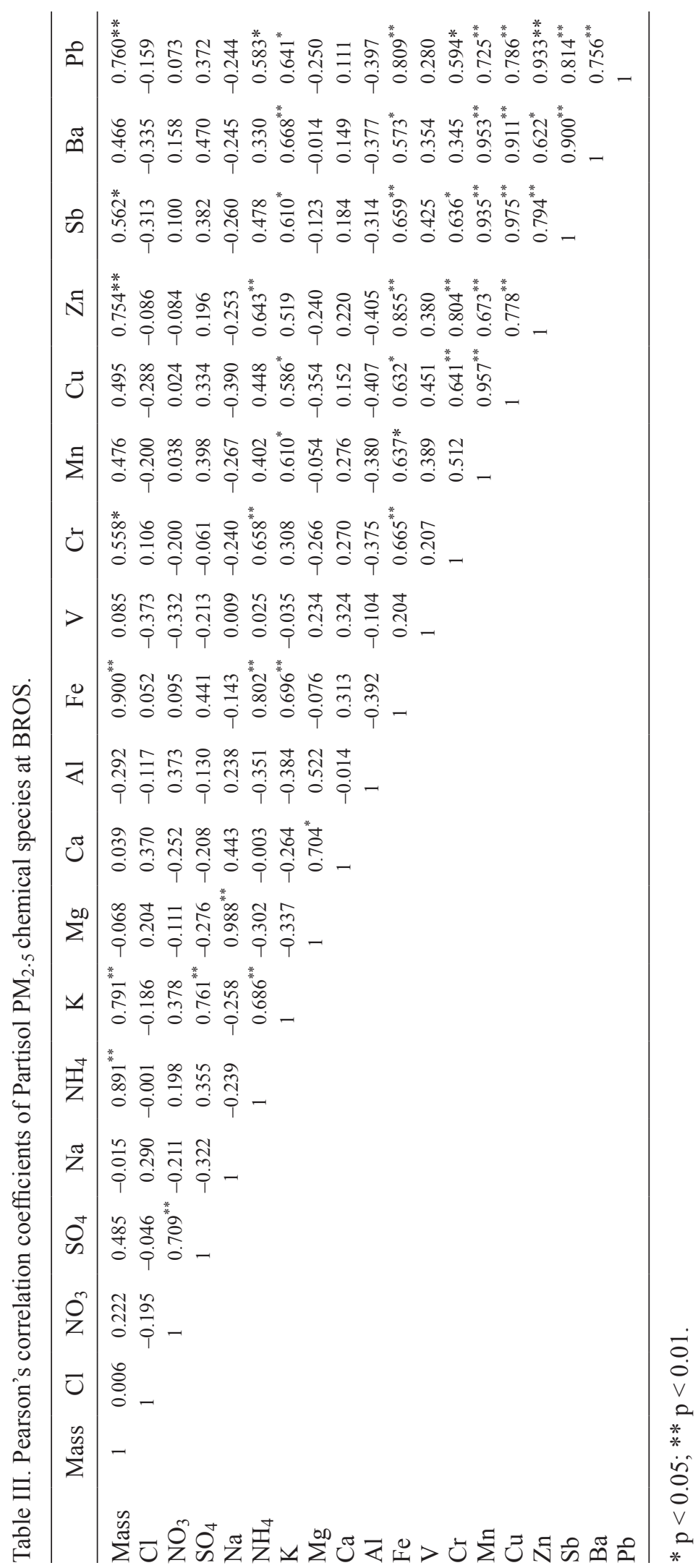




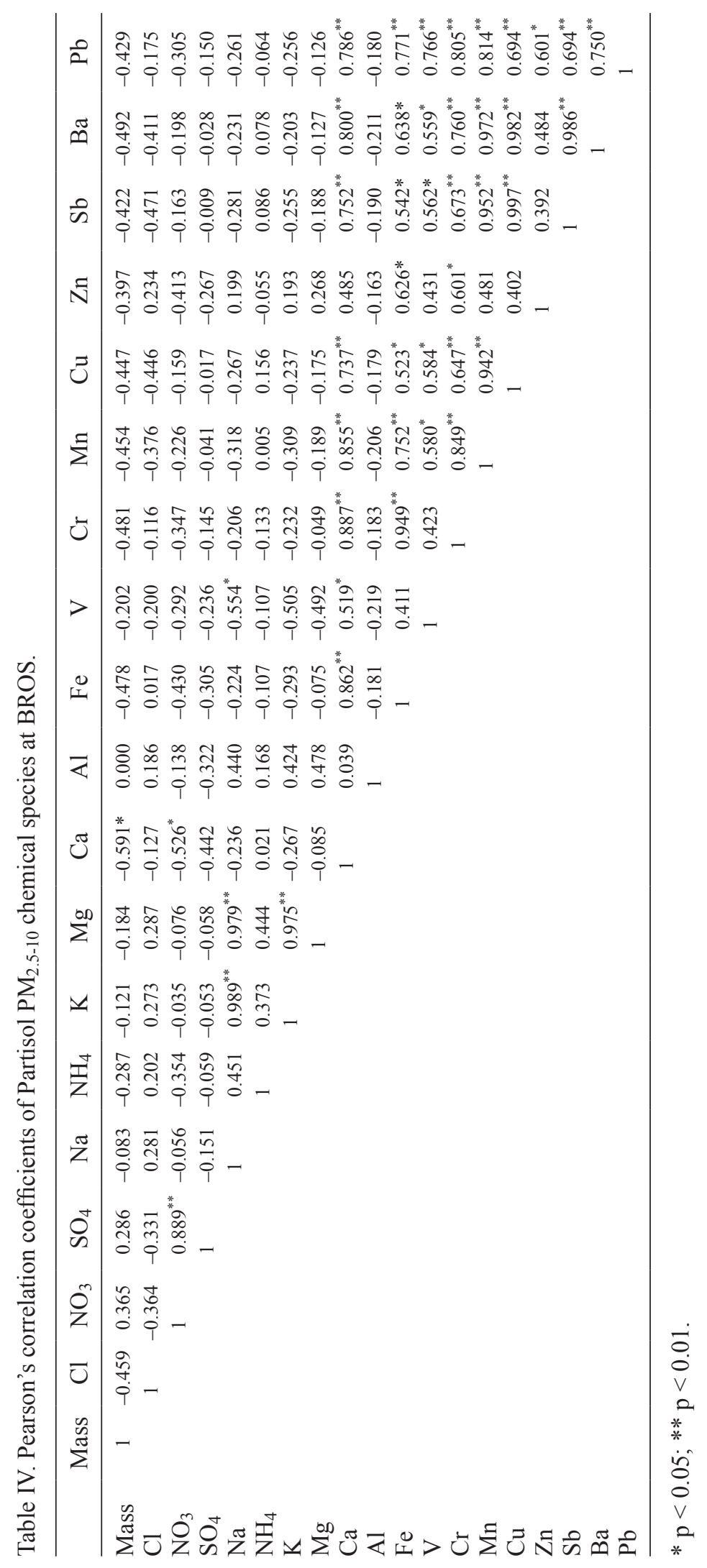


correlated. Traffic signatures of $\mathrm{Sb}, \mathrm{Fe}, \mathrm{Cu}, \mathrm{Zn}$ and $\mathrm{Ba}$ exhibited stronger correlations at BROS.

The sea salt aerosols $\left(\mathrm{Na}^{+}, \mathrm{Cl}^{-}\right)$are weakly correlated at BROS. In the $\mathrm{PM}_{2.5-10}$ fraction at BROS, mass concentration shows negative correlation with most observed constituents. $\mathrm{Na}^{+}, \mathrm{K}^{+}$and $\mathrm{Mg}^{2+}$ are strongly associated $(0.98-0.99 ; \mathrm{p}<0.01)$ in the coarse PM component at BROS, confirming probable influence from the road re-suspension dust. The traffic elements were also strongly associated at BROS for $\mathrm{PM}_{2.5-10}$ as observed in EROS.

Table V shows the inter-site relationship among the measured components of $\mathrm{PM}_{2.5}$ and $\mathrm{PM}_{2.5}$ at EROS and BROS. These sites are about $250 \mathrm{~m}$ apart; hence, they could be influenced by a related factor, being traffic the major suspect. Strong relationships

Table V. Inter-site correlations between PM in EROS and BROS.

\begin{tabular}{|c|c|c|c|}
\hline Components & $\begin{array}{l}\text { Coefficient } \\
\left(\mathrm{R}^{2}\right)\end{array}$ & Components & $\begin{array}{c}\text { Coefficient } \\
\left(\mathrm{R}^{2}\right)\end{array}$ \\
\hline $\mathrm{PM}_{2.5}$ mass & $0.87 * *$ & $\mathrm{Al}$ & 0.20 \\
\hline $\mathrm{Cl}^{-}$ & 0.55 & V & $0.92 * *$ \\
\hline $\mathrm{NO}_{3}^{-}$ & 0.12 & $\mathrm{Cr}$ & -0.17 \\
\hline $\mathrm{SO}_{4}^{2-}$ & 0.36 & $\mathrm{Mn}$ & $0.87 * *$ \\
\hline $\mathrm{Na}^{+}$ & 0.29 & $\mathrm{Fe}$ & $0.81 * *$ \\
\hline $\mathrm{NH}_{4}^{+}$ & $0.86^{* *}$ & $\mathrm{Cu}$ & $0.54 *$ \\
\hline $\mathrm{K}^{+}$ & $0.62 *$ & $\mathrm{Zn}$ & $0.92 * *$ \\
\hline $\mathrm{Mg}^{2+}$ & $0.68^{*}$ & $\mathrm{Sb}$ & $0.85^{* *}$ \\
\hline \multirow[t]{2}{*}{$\mathrm{Ca}^{2+}$} & \multirow[t]{2}{*}{0.44} & $\mathrm{Ba}$ & $0.89 * *$ \\
\hline & & $\mathrm{Pb}$ & $0.71 * *$ \\
\hline $\mathrm{PM}_{2.5-10}$ mass & -0.33 & $\mathrm{Al}$ & -0.10 \\
\hline $\mathrm{Cl}^{-}$ & $0.73 * *$ & V & $0.87 * *$ \\
\hline $\mathrm{NO}_{3}^{-}$ & 0.18 & $\mathrm{Cr}$ & 0.07 \\
\hline $\mathrm{SO}_{4}^{2-}$ & -0.01 & $\mathrm{Mn}$ & $0.84 * *$ \\
\hline $\mathrm{Na}^{+}$ & 0.22 & $\mathrm{Fe}$ & $0.86 * *$ \\
\hline $\mathrm{NH}_{4}^{+}$ & 0.30 & $\mathrm{Cu}$ & $0.88^{*}$ \\
\hline $\mathrm{K}^{+}$ & -0.20 & $\mathrm{Zn}$ & 0.48 \\
\hline $\mathrm{Mg}^{2+}$ & 0.05 & $\mathrm{Sb}$ & $0.91 * *$ \\
\hline \multirow[t]{2}{*}{$\mathrm{Ca}^{2+}$} & \multirow[t]{2}{*}{$0.90 * *$} & $\mathrm{Ba}$ & $0.91 * *$ \\
\hline & & $\mathrm{Pb}$ & $0.61 *$ \\
\hline
\end{tabular}

$* \mathrm{p}<0.05 ; * * \mathrm{p}<0.01$ were also observed at EROS and BROS for $\mathrm{PM}_{2.5}$ and $\mathrm{PM}_{2.5-10}$ components of $\mathrm{V}, \mathrm{Mn}, \mathrm{Fe}, \mathrm{Cu}, \mathrm{Zn}, \mathrm{Sb}$, $\mathrm{Ba}$ and $\mathrm{Pb}$. Species such as $\mathrm{NH}_{4}^{+}, \mathrm{K}^{+}, \mathrm{Mg}^{2+}$ and $\mathrm{Zn}$ showed better associations at EROS and BROS for fine PM; while $\mathrm{Cl}^{-}$and $\mathrm{Ca}^{2+}$ were better correlated in the coarse PM at the two sites.

\section{Discussion}

Most of the PM components (including mass concentrations) measured at the EROS background site were generally lower than those at BROS, a typical traffic-polluted site. This is not surprising due to the roadside increment of pollutants. Elemental difference between fine $\mathrm{SO}_{4}{ }^{2-}$ and coarse $\mathrm{NH}_{4}^{+}$at EROS and BROS were 245 and $262 \mathrm{ng} \mathrm{m}^{-3}$. Conversely, higher concentrations of coarse $\mathrm{SO}_{4}{ }^{2-}$ and fine $\mathrm{NH}_{4}^{+}$were measured at BROS with an incremental difference of 415 and $298 \mathrm{ng} \mathrm{m}^{-3}$, respectively. Since the two sites were within the University of Birmingham, insignificant regional transportation of these pollutants is expected (Harrison et al., 2004). The discrepancies in $\mathrm{NH}^{+}{ }_{4}$ measured at the two sites might be related to emission sources like biomass burning or incineration (Lim et al., 2010). Elevated coarse $\mathrm{SO}_{4}{ }^{2-}$ at BROS may be attributable to road resuspended dust or soil (Harrison et al., 1997). A large difference was found in nitrate concentrations between the two sites for fine $\left(875 \mathrm{ng} \mathrm{m}^{-3}\right)$ and coarse $\left(1108 \mathrm{ng} \mathrm{m}^{-3}\right) \mathrm{PM}$, which is an evidence of a distinctive roadside emission. Higher $\mathrm{PM}_{2.5}$ and $\mathrm{PM}_{2.5-10}$ mass concentrations at BROS also indicate traffic contributions from vehicular emissions and road re-suspension. Harrison et al. (1997) found a very strong correlation between $\mathrm{PM}_{2.5}$ and $\mathrm{NO}_{\mathrm{x}}$, suggesting that the $\mathrm{PM}_{2.5}$ mass concentration could be adopted as a better traffic signature.

This study showed elevated $\mathrm{SO}_{4}^{2-}$, lower $\mathrm{NO}_{3}^{-}$and $\mathrm{Cl}^{-}$values in the $\mathrm{PM}_{2.5}$ component relative to the research recently published by Laongsri and Harrison (2013) at EROS. In the $\mathrm{PM}_{2.5-10}$ component, $\mathrm{NO}_{3}^{-}$and $\mathrm{SO}_{4}^{2-}$ concentrations in this study are about two times higher than concentrations reported by Laongsri and Harrison (2013), but $\mathrm{Cl}^{-}$concentrations are lower. At BROS, a previous study of Yin et al. (2010) for $\mathrm{Cl}^{-}, \mathrm{SO}_{4}^{2-}, \mathrm{NO}_{3}^{-}, \mathrm{Ca}$ and $\mathrm{Fe}$ in $\mathrm{PM}_{10}$ found that these components represent approximately 3, 9, 6, 1 and $4 \%$ of the total measured mass, respectively. In this study, the corresponding values of these components 
in $\mathrm{PM}_{10}$ (computed by addition of $\mathrm{PM}_{2.5}$ and $\mathrm{PM}_{2.5-10}$ ) were 4, 12, 20, 2 and 5\%, respectively. Except for $\mathrm{NO}_{3}^{-}$, where a relatively higher fraction was measured, it appeared that the other observed components are in good agreement with Yin et al. (2010). The wide difference observed in the percentages of these secondary aerosols (nitrate and sulphate) relative to previously reported values at these sites might still be linked with regional influence rather than local emissions (Abdalmogith et al., 2006). Other probable reasons for this lack of agreement may be attributable to different sampling times and meteorological conditions.

Aluminum showed an increment for fine PM at BROS while the opposite occurred for coarse PM, which exhibited higher amounts at EROS. Fine Al can be attributed to vehicular emissions while coarse Al may take its source from soil. Traffic signatures such as $\mathrm{Zn}, \mathrm{Fe}, \mathrm{Cu}, \mathrm{Ba}, \mathrm{Mn}$ and $\mathrm{Pb}$ (Thorpe and Harrison, 2008) showed greater concentrations in fine and coarse PM at BROS, which agrees with studies conducted at roadsides (Amato et al., 2009, 2011; Gietl et al., 2010). Pearson correlation coefficients depicted in Table I revealed strong significant correlations among these traffic signatures for $\mathrm{PM}_{2.5-10}$ showing the pronounced contribution by traffic at both sites.

The $\mathrm{PM}_{2.5} / \mathrm{PM}_{10}$ ratios observed at EROS and BROS showed dominance of anthropogenic emissions at the two sites. This is comparable to most studies reported at urban sites. The earlier study of Yin and Harrison (2008) has observed $\mathrm{PM}_{2.5} / \mathrm{PM}_{10}$ ratio of 0.60 at BROS in perfect agreement with this present study. In the Harrison et al. (2004) study at an urban background site in London (High Holborn), the ratio of $\mathrm{PM}_{2.5} / \mathrm{PM}_{10}$ was calculated as 0.62 while the value was 0.64 at the roadsides. Across the UK, the mean ratio of $\mathrm{PM}_{2.5-10} / \mathrm{PM}_{10}$ has been reported as $0.31 \pm 0.13$ (Liu and Harrison, 2011). This indicates dominance of $\mathrm{PM}_{2.5}$ in agreement with observations at BROS and EROS.

\section{Conclusions}

The above-mentioned data of EROS and BROS depicts higher concentrations of most PM parameters at the BROS site, which reflects the roadside increment. Sulphate was the most preponderant fine particle at EROS (17\% of the $\mathrm{PM}_{2.5}$ mass), while nitrate was predominant at BROS (20\%). In the coarse fraction, nitrate was the highest chemical component at both sites (15 and 24\% at EROS and BROS, respectively). The measured chemical components of PM (ionic and metal species) constituted only 51 and $54 \%$ of $\mathrm{PM}_{2.5}$, and $54 \%$ and $67 \%$ of $\mathrm{PM}_{2 \cdot 5-10}$ at EROS and BROS, respectively. The remaining components can be attributed to the unmeasured carbonaceous species, mass-associated oxygen, particle-bound water and other chemical constituents.

\section{Acknowledgments}

The author is grateful to the Tertiary Education Trust Fund of the Federal University of Agriculture, Abeokuta, Nigeria for sponsoring my research work at the University of Birmingham, UK.

\section{References}

Abdalmogith S.A., R.M. Harrison and R.G. Derwen, 2006. Particulate sulphate and nitrate in Southern England and Northern Ireland during 2002/3 and its formation in a photochemical trajectory model. Sci. Tot. Environ. 368, 769-780.

doi: 10.1016/j.scitotenv.2006.02.047

Amato F., M. Pandolfi, A. Escrig, X. Querol, A. Alastuey, J. Pey, N. Prez and P.K. Hopke, 2009. Quantifying road dust resuspension in urban environment by Multilnear Engine: A comparison with PMF2. Atmos. Environ. 43, 2770-2780. doi: 10.1016/j.atmosenv.2009.02.039 Anenberg S.C., L.W. Horowitz, D.Q. Tong and J.J. West, 2010. An estimate of the global burden of anthropogenic ozone and fine particulate matter on premature human mortality using atmospheric modeling. Environ. Health Perspect. 118, 1189-1195.

doi: 10.1289/ehp.0901220

Charron A. and R.M. Harrison, 2005. Fine $\left(\mathrm{PM}_{2.5}\right)$ and coarse $\left(\mathrm{PM}_{2.5-10}\right)$ particulate matter on a heavily trafficked London highway: Sources and processes. Environ. Sci. Technol. 39, 7768-7776.

doi: 10.1021/es050462i

Chung Y.-S., S.-H. Kim, J.-H. Moon, Y.-J. Kim, J.-M. Lim and J.-H. Lee, 2006. Source identification and longterm monitoring of airborne particulate matter (PM2.5 / PM10) in an urban region of Korea. J. Radioanal. Nucl. Chem. 267, 35-48. doi: 10.1007/s10967-006-0006-Z

Gietl J.K., R. Lawrence, A.J. Thorpe and R.M. Harrison, 2010. Identification of brake wear particles and derivation of a quantitative tracer for brake dust at a major 
road. Atmos. Environ. 44, 141-146.

doi: 10.1016/j.atmosenv.2009.10.016

Harrison R.M., A.R. Deacon and M.R. Jones, 1997. Sources and processes affecting concentrations of $\mathrm{PM}_{10}$ and $\mathrm{PM}_{2.5}$ particulate matter in Birmingham (U.K.). Atmos. Environ. 31, 4103-4117. doi: 10.1016/S1352-2310(97)00296-3

Harrison R.M., A.M. Jones and R.G. Lawrence, 2003. A pragmatic mass closure model for airborne particulate matter at urban background and roadside sites. Atmos. Environ. 37, 4927-4933. doi: 10.1016/j.atmosenv.2003.08.025

Harrison R.M., A.M. Jones and R.G. Lawrence, 2004. Major component composition of $\mathrm{PM}_{10}$ and $\mathrm{PM}_{2.5}$ from roadside and urban background sites. Atmos. Environ. 38, 4531-4538. doi: /10.1016/j.atmosenv.2004.05.022

Harrison R.M., D. Laxen, S. Moorcroft and K. Laxen, 2012. Processes affecting concentrations of fine particulate matter $\left(\mathrm{PM}_{2.5}\right)$ in the UK atmosphere. Atmos. Environ. 46, 115-124. doi: 10.1016/j.atmosenv.2004.05.022

Kleeman M.J., J.J. Schauer and G.R. Cass, 2000. Size and composition distribution of fine particulate matter emitted from motor vehicles. Environ. Sci. Technol. 34, 1132-1142. doi: 10.1021/es981276y

Laongsri B. and R.M. Harrison, 2013. Atmospheric behaviour of particulate oxalate at UK urban background and rural sites. Atmos. Environ. 71, 319-326. doi: 10.1016/j.atmosenv.2013.02.015

Levy J.I., D.H. Bennett, S.J. Melly and J.D. Spengler, 2003. Influence of traffic patterns on particulate matter and polycyclic aromatic hydrocarbon concentrations in Roxbury, Massachusetts. J. Expo. Anal. Environ. Epidermiol. 13, 364-71. doi: 10.1038/sj.jea.7500289

Lim J.-M., J.-H. Lee, J.-H. Moon, Y.-S. Chung and K.-H. Kim, 2010. Source apportionment of $\mathrm{PM}_{10}$ at a small industrial area using positive matrix factorization. Atmos. Res. 95, 88-100.

doi: 10.1016/j.atmosres.2009.08.009

Liu J.-Y. and R.M. Harrison, 2011. Properties of coarse particles in the atmosphere of the United Kingdom. Atmos. Environ. 45, 3267-3276.

doi: 10.1016/j.atmosenv.2011.03.039

Mazzei F., A. D’Alessandro, F. Lucarelli, S. Nava, P. Prati, G. Valli and R. Vecchi, 2008. Characterization of particulate matter sources in an urban environment.
Sci. Tot. Environ. 401, 81-89.

doi: 10.1016/j.scitotenv.2008.03.008

Mysliwiec M.J. and M.J. Kleeman, 2002. Source apportionment of secondary airborne particulate matter in a polluted atmosphere. Environ. Sci. Technol. 36, 53765384. doi: 10.1021/es020832s

Taiwo A.M., D.C.S. Beddows, Z. Shi and R.M. Harrison, 2014. Mass and number size distributions of particulate matter components: Comparison of an industrial site and an urban background site. Sci. Tot. Environ. 475, 29-38.

doi: 10.1016/j.scitotenv.2013.12.076

Thermo Fischer Scientific Inc., 2012. Dionex ICS-2100 Ion Chromatography System Operator's Manual. Document No. 065291. Available at: http://www.dionex. com/en-us/webdocs/73382- Man-IC-IC S2100-Operators-Oct2012-DOC065291-03.pdf (last accessed on August 8, 2013).

Thorpe A. and R.M. Harrison, 2008. Sources and properties of non-exhaust particulate matter form road traffic: a review. Sci. Tot. Environ. 400, 270-282.

doi: 10.1016/j.scitotenv.2008.06.007

Watkiss P., S. Pye and M. Holland, 2005. Baseline scenarios for service contract for carrying out cost-benefit analysis of air quality related issues, in particular in the Clean Air for Europe (CAFE) programme. AEAT/ ED51014/ Baseline Issue 5. Didcot, United Kingdom.

WHO, 2009. Global health risks: Mortality and burden of disease attributable to selected major risks. World Health Organization, Geneva. Available at: http://whqlibdoc.who.int/publications/2009/9789241563871_ eng.pdf (last accessed on July 17, 2013).

Xia L. and Y. Gao, 2010. Chemical composition and size distributions of coastal aerosols observed on the US East Coast. Mar. Chem. 119, 77-90. doi: 10.1016/j.marchem.2010.01.002

Yin J. and R.M. Harrison, 2008. Pragmatic mass closure study for $\mathrm{PM}_{1.0}, \mathrm{PM}_{2.5}$ and $\mathrm{PM}_{10}$ at roadside, urban background and rural sites. Atmos. Environ. 40, 980988. doi: 10.1016/j.atmosenv.2007.10.005

Yin J., R.M. Harrison, Q. Chen, A. Rutter and J.J. Scauer, 2010. Source apportionment of fine particles at urban background and rural sites in the UK atmosphere. Atmos. Environ. 44, 841-851. doi: 10.1016/j.atmosenv.2009.11.026 